W niniejszym dziale zamieszczamy wybrane streszczenia rozpraw doktorskich dotyczących chorób nowotworowych, obronionych przed Radą Naukową Centrum Onkologii Instytutu im. M. Skłodowskiej-Curie oraz w innych ośrodkach naukowych w kraju. Zachęcamy Doktorantów do kontaktu z Redakcją Nowotworów i nadsyłanie propozycji na adres: redakcja@coi.waw.pl.

Inną możliwością publikacji doktoratu, do której również zachęcamy, jest przedstawienie go w obszerniejszej formie — w postaci klasycznej pracy oryginalnej.

\title{
Analiza przydatności wybranych czynników ryzyka, badań biochemicznych i echokardiograficznych w monitorowaniu powikłań sercowo-naczyniowych u chorych leczonych trastuzumabem
}

\author{
Aleksandra Grela-Wojewoda \\ Promotor: dr hab. Mieczysław Pasowicz, prof. nadzw. \\ Recenzenci: prof. dr hab. Jarosław Drożdż, dr hab. Jerzy Jakubowicz, prof. nadzw. \\ Data obrony: 12 marca 2014 r.
}

Rak piersi jest najczęściej występującym na świecie nowotworem złośliwym u płci żeńskiej i stanowi w większości krajów około 23\% zachorowań na nowotwory złośliwe wśród kobiet. Co roku odnotowuje się około 1300000 nowych zachorowań na raka piersi i około 400000 zgonów spowodowanych tą chorobą. Polska należy do krajów o średniej zachorowalności na raka piersi i również tutaj jest to najczęściej występujący nowotwór złośliwy u kobiet (22\%). Standaryzowany współczynnik zachorowalności wynosi 47,7/100 000 osób. Rak piersi najczęściej (57\%) jest rozpoznawany w grupie wiekowej 50-69 lat. Od lat 80. XX wieku obserwuje się stały wzrost zachorowalności na raka piersi, natomiast umieralność pozostaje na niezmienionym poziomie. Szacuje się, że w latach 2010-2025 nastąpi dalszy wzrost zachorowalności na raka piersi we wszystkich grupach wiekowych. Największe ryzyko zachorowania dotyczy grupy wiekowej 50-69 lat i w tej populacji zaleca się wykonywanie badań przesiewowych. Leczenie raka piersi ma charakter wielodyscyplinarny. Kompleksowe postępowanie wymaga współpracy specjalistów w wielu dziedzinach: radiologa, patomorfologa, chirurga onkologa, onkologa klinicznego, radioterapeuty, chirurga plastycznego, kardioonkologa, rehabilitanta i psychoonkologa. Radykalne leczenie przedinwazyjnego i wczesnego inwazyjnego raka piersi wymaga w pierwszej kolejności leczenia chirurgicznego. W zależności od wskazań indywidualnych stosuje się uzupełniającą radioterapię oraz leczenie systemowe (chemioterapia, hormonoterapia, immunoterapia). Zgodnie z zaleceniami Konferencji z St. Gallen z 2013 roku w podejmowaniu decyzji o leczeniu uzupełniającym należy się kierować podtypem immunohistochemicznym nowotworu. Nadekspresja receptora HER2 i/lub amplifikacja genu występuje w 20-30\% inwazyjnych raków piersi i jest negatywnym czynnikiem prognostycznym oraz wskaźnikiem predykcyjnym korzyści z zastosowania terapii biologicznych takich jak: podawanie trastuzumabu, lapatynibu, pertuzumabu.

U kobiet z rozpoznaniem wczesnego HER2-dodatniego raka piersi stosowanie trastuzumabu w leczeniu uzupełniającym zmniejsza ryzyko nawrotu choroby oraz wydłuża czas przeżycia całkowitego (overall survival — OS). Wskazaniem do uzupełniającego leczenia trastuzumabem jest rozpoznanie HER2-dodatniego raka piersi z guzem o średnicy $>1 \mathrm{~cm}$ (T1c) lub w przypadku przerzutów w pachowych węzłach chłonnych, z wyjątkiem chorych z cechą T4 (stopień IIIB) i przerzutami do 10 lub więcej węzłów chłonnych (stopień IIIC). Trastuzumab jest lekiem dobrze tolerowanym, ale u części pacjentek może powodować powikłania kardiologiczne. Zgodnie z „Rekomendacjami Krajowego Zespołu Nadzoru Kardiologicznego i Onkologicznego (...)” oraz wytycznymi European Society for Medical Oncology (ESMO) przed rozpoczęciem leczenia należy ocenić stan układu sercowo-naczyniowego oraz prowadzić monitorowanie kardiologiczne podczas i po zakończeniu immunoterapii.

Celem pracy była:

— ocena częstości występowania i określenie rodzajów powikłań kardiologicznych u pacjentów leczonych trastuzumabem, 
- ocena występowania powikłań kardiologicznych podczas stosowania trastuzumabu u pacjentek, u których istniały czynniki ryzyka sercowo-naczyniowego i u chorych po przebytym leczeniu onkologicznym (chemioterapii, radioterapii, hormonoterapii),

- zbadanie zależności pomiędzy wystąpieniem echokardiograficznych cech niedomykalności zastawek w czasie leczenia trastuzumabem a wartością frakcji wyrzutowej lewej komory oraz objawami klinicznymi kardiotoksyczności,

— określenie, czy wzrost poziomu wartości biomarkerów kardiologicznych (pro-BNP, mioglobiny, CK-MB) w stosunku do wartości sprzed leczenia trastuzumabem koreluje z występowaniem powikłań kardiologicznych i spadkiem frakcji wyrzutowej lewej komory.

Metodykę badania oparto na analizie danych zebranych podczas leczenia 130 kobiet z rozpoznaniem raka piersi, leczonych w Instytucie Onkologii w Krakowie uzupełniająco trastuzumabem w okresie od 2008 r. do 2012 r. Wszystkie pacjentki wykazywały nadekspresję receptora HER2 i/lub amplifikację genu, były po radykalnym leczeniu operacyjnym (amputacja piersi sposobem Maddena lub zabieg oszczędzający), uzupełniającej chemioterapii, radioterapii (w zależności od indywidualnych wskazań), w trakcie hormonoterpii (w przypadku dodatnich receptorów hormonalnych).

Ustalono następujące kryteria oceny wyników:

- choroby współistniejące (nadciśnienie tętnicze, choroba niedokrwienna serca, cukrzyca),

— zaburzenia metaboliczne (nieprawidłowy profil lipidowy, nietolerancja glukozy, podwyższona wartość wskaźnika masy ciała [BMI]),

- rodzaj zastosowanego leczenia przeciwnowotworowego (chemioterapia, radioterapia, hormonoterapia),

- pojawienie się niedomykalności zastawek serca a wartość frakcji wyrzutowej lewej komory LVEF,

- ocena przydatności biomarkerów kardiologicznych (pro-BNP, mioglobina, CK-MB) w przewidywaniu wystąpienia powikłań kardiologicznych.

U wszystkich chorych wykonywano badanie podmiotowe, przedmiotowe, echokardiograficzne oraz badanie krwi przed rozpoczęciem leczenia, w trakcie i po zakończeniu immunoterapii. Na tej podstawie rozpoznawano pojawiające się powikłania kardiologiczne i - w zależności od rodzaju, nasilenia i utrzymywania się objawów - czasowo przerywano lub wcześniej kończono immunoterapię. Jednocześnie, w zależności od indywidualnych wskazań, wdrażano adekwatne leczenie kardiologiczne. W analizie statystycznej oceniano istotność wpływu szeregu czynników na wystąpienie powikłań kardiologicznych podczas leczenia trastuzumabem. We wszystkich analizach przyjęto, że istotne statystycznie są wyniki, dla których $p<0,05$, a wyniki z wartością p wahającą się pomiędzy 0,05 a 0,1 potraktowano jako wskazujące tendencję do istotności.

Powikłanie kardiologiczne podczas leczenia uzupełniającego trastuzumabem wystąpiły u 24 spośród 130 pacjentek (18,46\%) leczonych. U 14 pacjentek (10,77\%) spowodowały one wcześniejsze zakończenie leczenia, a u 10 (7,69\%) po czasowym przerwaniu immunoterapii dokończono terapię. Występowanie chorób współistniejących, zaburzenia metaboliczne i przebyte leczenie onkologiczne nie miały wpływu na częstość powikłań kardiologicznych. Stwierdzono częstsze występowanie powikłań kardiologicznych u pacjentek z podwyższonym BMI i u tych, które otrzymały większą dawkę antracyklin.

W wyniku przeprowadzonych analiz wysunięto następujące wnioski:

1. Powikłania kardiologiczne $w$ trakcie leczenia uzupełniającego trastuzumabem u pacjentek z rozpoznaniem raka piersi i nadekspresją receptora HER2 występują pod postacią spadku frakcji wyrzutowej lewej komory, niewydolności układu krążenia, niedomykalności zastawek, zaburzeń rytmu serca i przewodzenia oraz nasilenia objawów choroby niedokrwiennej. Przy przyjętych kryteriach powikłania te były przyczyną wcześniejszego zakończenia immunoterapii u 10\% chorych, przy czym niewydolność krążenia w stopniu III lub IV wg NYHA wystąpiła u 4\% pacjentek.

2. Występowanie czynników ryzyka sercowo-naczyniowego, takich jak: choroba niedokrwienna serca, nadciśnienie tętnicze, cukrzyca, nieprawidłowy profil lipidowy, podwyższony indeks masy ciała (BMI) nie wpływa na występowanie powikłań kardiologicznych w trakcie leczenia trastuzumabem. Rysuje się tendencja do częstszego występowania powikłań kardiologicznych w grupie chorych z podwyższonym indeksem masy ciała (BMI).

3. Rodzaj stosowanego uzupełniającego leczenia onkologicznego (chemioterapia, radioterapia, hormonoterapia) zasadniczo nie wpływa na częstość powikłań kardiologicznych, jednak rysuje się zależność występowania objawów kardiotoksyczności od otrzymanej dawki antracyklin, które występują częściej u chorych, które otrzymały ich wyższą dawkę.

4. Stwierdzono, na podstawie badania echokardiograficznego, że częste (75\%) występowanie de novo niedomykalności zastawek serca oraz istotny statystycznie w tej grupie pacjentek spadek frakcji wyrzutowej lewej komory (LVEF) nie wpływa na występowanie objawów klinicznych kardiotoksyczności.

5. Podwyższone wartości stężeń biomarkerów kardiologicznych (pro-BNP, CK-MB, mioglobina) przed rozpoczęciem leczenia i w trakcie leczenia nie korelują z występowaniem kardiotoksyczności i spadkiem frakcji wyrzutowej lewej komory. 


\title{
Odległe wyniki leczenia chorych na gruczolaki jelita grubego $z$ inwazyjnym rakiem
}

\author{
Jolanta Nałęcz-Janik
}

Promotor: prof. dr hab. Witold Bartnik

Recenzenci: prof. dr hab. Barbara Skrzydło-Radomańska, prof. dr hab. Teresa Starzyńska

Data obrony: 24 września 2014 r.

Około 5\% gruczolaków jelita grubego usuniętych endoskopowo zawiera utkanie inwazyjnego raka. Część tych chorych jest leczona tylko endoskopowo, a części z nich proponuje się resekcję jelita.

Celami rozprawy były:

1. Ocena odległych wyników leczenia endoskopowego pacjentów z gruczolakami jelita grubego zawierającymi utkanie inwazyjnego raka.

2. Zbadanie, czy zmodyfikowanie kryteriów leczenia endoskopowego poprzez przyjęcie zmniejszonego do $\geq 1 \mathrm{~mm}$ marginesu wolnego od nacieku raka i dodanie objawu „pączkowania” nowotworu miałoby wpływ na decyzje lecznicze i losy chorych.

Materiał chorych liczył 128 osób, u których w latach 1979-2005 usunięto endoskopowo 130 gruczolaków z inwazyjnym rakiem. 61 chorym, u których gruczolaki z rakiem spełniały klasyczne kryteria mikroskopowe wystarczalności leczenia endoskopowego, zaproponowano tylko obserwację. Wynik leczenia tych chorych, obserwowanych przez okres średnio 69,2 miesiąca (mediana 70,43; IQR 41,9), jest bardzo dobry. Pozostałym 67 chorym, u których nie były spełnione kryteria wystarczalności leczenia endoskopowego, zaproponowano uzupełniającą resekcję odcinkową jelita. Operacji poddano 32 chorych, z których 27 miało ostatecznie dobry wynik leczenia. Taki sam wynik zaobserwowano u 30 spośród 35 osób, których nie operowano, mimo że operacja była zalecana. Łącznie na 128 chorych dobry wynik leczenia endoskopowego lub endoskopowego i chirurgicznego miało $92 \%$ wszystkich chorych.

Niepowodzenia leczenia ( $w$ tym 2 zgony z powodu raka jelita grubego) obserwowano u 10 osób (8\%). Byli to wyłącznie chorzy, których gruczolaki z rakiem nie spełniały klasycznych kryteriów wystarczalności leczenia endoskopowego.

W grupie 85 osób zbadano skutki przyjęcia mniejszego marginesu wolnego od nacieku raka oraz dodania jako kryterium mikroskopowego objawu „pączkowania” nowotworu (obecność komórek raka, pojedynczych lub w skupieniach do 5 komórek, w obszarze naciekania nowotworu). Przyjęcie marginesu zmniejszonego z $\geq 2 \mathrm{~mm}$ do $\geq 1 \mathrm{~mm}$ spowodowałoby zwiększenie o 15\% grupy chorych, której z zachowaniem pełnego bezpieczeństwa onkologicznego można by zaproponować samą obserwację po polipektomii endoskopowej. Oznacza to, że taka modyfikacja szerokości marginesu wolnego od zmian zaoszczędziłaby części chorych (13\%) operacji brzusznej. Dodanie do kryteriów mikroskopowych objawu „pączkowania” nowotworu nie miałoby wpływu na postępowanie ani na losy chorych z gruczolakami jelita grubego zawierającymi inwazyjnego raka.

Wnioski z rozprawy są następujące:

1. Długotrwała obserwacja dużej grupy chorych potwierdza skuteczność i bezpieczeństwo onkologiczne endoskopowego leczenia gruczolaków jelita grubego zawierających inwazyjnego raka.

2. Modyfikacja kryteriów mikroskopowych wystarczalności leczenia endoskopowego gruczolaków z inwazyjnym rakiem może korzystnie zmienić proporcje chorych, którym po polipektomii proponuje się samą obserwację lub uzupełniającą resekcję jelita. 


\title{
Znaczenie pooperacyjnego podania jodu promieniotwórczego ( $\left.{ }^{131} \mathrm{I}\right)$ w skojarzonym leczeniu zróżnicowanego raka tarczycy (ZRT)
}

\author{
Jolanta Krajewska
}

Promotor: prof. dr hab. n. med. Barbara Jarząb

Recenzenci: prof. dr hab. n. med. Ewa Bar-Andziak, prof. dr hab. n. med. Izabela Kozłowicz-Gudzińska

Data obrony: 13 stycznia 2014 r.

Uzupełniające leczenie (UL) ${ }^{131}$ I po całkowitym wycięciu tarczycy jest obecnie podstawową strategią postępowania u chorych na ZRT. Jednak od około 10 lat zakres wskazań do UL ${ }^{131} \mathrm{I}$ jest przedmiotem dyskusji. Zalecenia europejskie i amerykańskie zgodnie rekomendują UL ${ }^{131}$ I u chorych z grupy wysokiego ryzyka (T3, T4 i/lub N1), ale kwestionują zasadność jego rutynowego stosowania w grupie chorych o niższym zaawansowaniu z uwagi na brak przekonywających dowodów skuteczności.

Hipoteza wyjściowa: Jeżeli UL ${ }^{131}$ I nie ma znaczenia dla chorych niskiego ryzyka, to leczenie przeprowadzone z opóźnieniem nie będzie się różniło odległym wynikiem, ocenianym jako częstość nawrotu w porównaniu do terapii o czasie.

Celem pracy była retrospektywna ocena wyników odległych leczenia skojarzonego ZRT u chorych radykalnie operowanych dla oceny znaczenia UL ${ }^{131}$ I w grupie z mniej zaawansowaną chorobą.

Grupa badana obejmowała 510 chorych M0 (409 kobiet, 101 mężczyzn, średni wiek w chwili rozpoznania raka 42,2 roku) z rozpoznaniem ZRT w stopniu > pT1aN0, u których całkowite wycięcie tarczycy przeprowadzono do roku od rozpoznania, a UL ${ }^{131}$ I — do 24 miesięcy od zakończonego leczenia operacyjnego. U 362 chorych (71\%) stwierdzono raka brodawkowatego, a u 148 (29\%) raka pęcherzykowego. W oparciu o klasyfikację TNM (wersja z 1997 r.) u 59 (11,6\%) chorych stwierdzono cechę T1, u 179 (35,1\%) - T2, u 43 (8,4\%) - T3, u 48 (9,4\%) - T4 a w 181 (35,5\%) przypadkach — Tx. Przerzuty do węzłów chłonnych (N1) były obecne u 126 (24,7\%) chorych. Mediana obserwacji wynosiła 12,1 roku (zakres 1,5-15,2).

Na podstawie analizy wieloczynnikowej wyłoniono czynniki ryzyka wpływające na czas do progresji ZRT (FFP). Najistotniejszym czynnikiem rokowniczym było pooperacyjne stężenie stymulowanej Tg: jeżeli wynosiło > $30 \mathrm{ng} / \mathrm{ml}$, to ryzyko nawrotu było 6-krotnie większe. Cecha N1 wiązała się z blisko 4-krotnym zwiększeniem ryzyka nawrotu ZRT. Kolejne niezależne czynniki to: średnica guza, wiek w chwili rozpoznania oraz pooperacyjny wychwyt ${ }^{131}$ I w loży tarczycy (T24). Ryzyko nawrotu w grupie badanej wynosiło 12,55\%. Mediana FFP - 154,8 miesiąca [95\% Cl: 150,4-159,4 miesiąca]. Pięcioletni odsetek chorych bez nawrotu wynosił 90,1\%, a 10-letni — odpowiednio 87,5\%.

Aby ocenić skuteczność UL ${ }^{131} \mathrm{I}$, badaną grupę podzielono na 3 klasy zależnie od wyjściowego zaawansowania ZRT (T;N) i pooperacyjnego stężenia Tg stymulowanej: klasa I"NISKIEGO RYZYKA" — chorzyT1-T3, N0-Nx,Tg < $10 \mathrm{ng} / \mathrm{ml}(\mathrm{n}=272)$; klasa II „POŚREDNIEGO RYZYKA" - chorzyT1-T3, Tg 10-30ng/ml + chorzyT1-T3, N1, Tg $<10$ ng/ml + chorzy T4 N0-N1, Tg $<10 \mathrm{mg} / \mathrm{ml}$ ( $\mathrm{n}=148$ ); klasa III "WYSOKIEGO RYZYKA" — chorzy T4 lub N1 i Tg 10-30 ng/ml + chorzy Tg > $30 \mathrm{mg} / \mathrm{ml}$ ( $\mathrm{n}=90$ ). Porównano podgrupę chorych leczonych do 9 miesięcy od rozpoznania raka z podgrupą chorych leczonych w okresie 9-24 i >24 miesięcy. W klasie I, w podgrupie z UL ${ }^{131}$ I do 9 miesięcy, nie obserwowano żadnych nawrotów, podczas gdy wśród chorych leczonych w okresie 9-24 miesięcy i > 24 miesięcy ryzyko nawrotu wynosiło odpowiednio 5,5\% i 7,1\%. Różnice te były znamienne statystycznie. W klasie II i III nie stwierdzono istotnych różnic pomiędzy chorymi leczonymi ${ }^{131}$ I do 9 miesięcy, 9-24 miesięcy i powyżej 24 miesięcy od chwili rozpoznania raka, tak więc odrzucono hipotezę wyjściową.

Na podstawie przeprowadzonych analiz sformułowano następujące wnioski:

1. W analizowanej grupie chorych na ZRT w stopniu pT1b-T4N0-1M0, poddanych całkowitemu wycięciu tarczycy, UL ${ }^{131}$ I prowadziło do doskonałego efektu terapii - bez nawrotu pozostaje 87,5\% badanych chorych po ponad 11-letnim średnim czasie obserwacji.

2. UL ${ }^{131}$ I powinno być przeprowadzone, także u chorych niskiego ryzyka, w krótkim czasie po operacji. W pracy wykazano, że chorzy ci charakteryzują się doskonałym rokowaniem, jeśli całość leczenia od rozpoznania mieści się w 9 miesiącach. Naszym zdaniem wyłączenie tych chorych z leczenia radiojodem, sugerowane przez rekomendacje ATA i ETA, jest nieuzasadnione.

3. Histopatologiczne wykładniki agresywności nowotworu, takie jak naciekanie torebki, wieloogniskowość guza czy angioinwazja, nie są w populacji chorych leczonych uzupełniająco ${ }^{131}$ I niezależnymi czynnikami rokowniczymi. W przeciwieństwie do nich zaawansowanie nowotworu (średnica guza i zajęcie węzłów chłonnych) jest silnym czynnikiem rzutującym na ryzyko nawrotu. 
4. Najsilniejszym pojedynczym czynnikiem rokowniczym jest ocena pooperacyjnego stężenia tyreoglobuliny stymulowanej, badanego przed UL ${ }^{131}$.

5. U chorych poddanych UL ${ }^{131} \mathrm{I}$, u których pooperacyjny T24 był niski (< 1\%), obserwowano gorsze wyniki leczenia — cecha ta w analizie wieloczynnikowej była istotna statystycznie. Wskazuje to na błąd w stosowanych w ówczesnym czasie kryteriach kwalifikacji do leczenia.

Dr n. med. Jolanta Krajewska Zakład Medycyny Nuklearnej i Endokrynologii Onkologicznej, Centrum Onkologii — Instytut im. M. Skłodowskiej-Curie, Oddział w Gliwicach e-mail:jolaakraj@gmail.com 